Nevada

Environmental

Restoration

Project

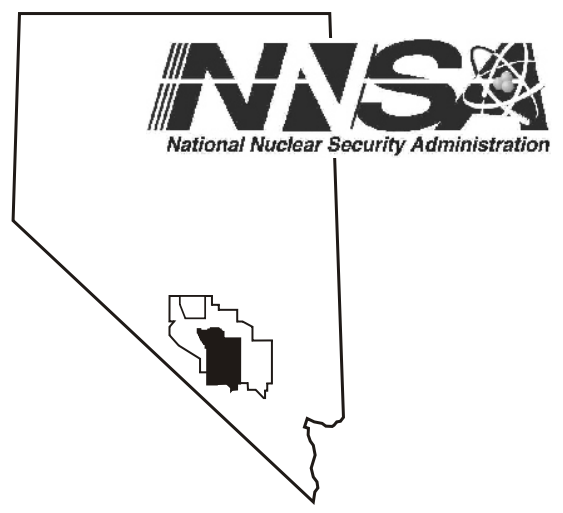

Corrective Action Plan

For Corrective Action Unit 536:

Area 3 Release Site,

Nevada Test Site, Nevada

Controlled Copy No.:

Revision: 0

September 2005

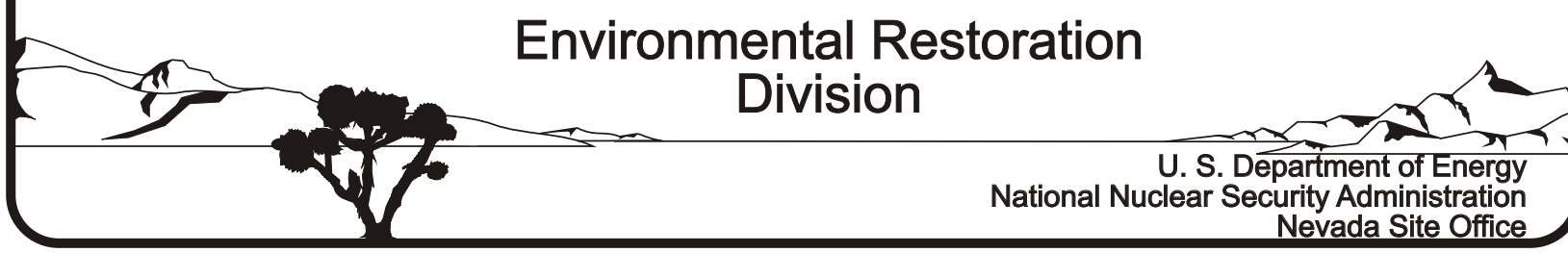




\section{DISCLAIMER}

Reference herein to any specific commercial product, process, or service by trade name, trademark, manufacturer, or otherwise, does not necessarily constitute or imply its endorsement, recommendation, or favoring by the United States Government or any agency thereof or its contractors or subcontractors.

This report has been reproduced directly from the best available copy.

Available for sale to the public from:

U.S. Department of Commerce

National Technical Information Service

5285 Port Royal Road

Springfield, VA 22161-0002

Telephone: (800) 553-6847

Fax: (703) 605-6900

E-mail: orders@ntis.gov

Online ordering: http://www.ntis.gov/ordering.htm

Available electronically at http://www.osti.gov/bridge.

Available for a processing fee to the U.S. Department of Energy and its contractors, in paper, from:

U.S. Department of Energy

Office of Scientific and Technical Information

P.O. Box 62

Oak Ridge, TN 37831-0062

Telephone: (865) 576-8401

Fax: (865) 576-5728

E-mail: reports@adonis.osti.gov 


\title{
CORRECTIVE ACTION PLAN FOR CORRECTIVE ACTION UNIT 536: AREA 3 RELEASE SITE, NEVADA TEST SITE, NEVADA
}

\author{
U.S. Department of Energy \\ National Nuclear Security Administration \\ Nevada Site Office \\ Las Vegas, Nevada
}

Controlled Copy No.

Revision: 0

September 2005 
THIS PAGE INTENTIONALLY LEFT BLANK 


\section{CORRECTIVE ACTION PLAN FOR CORRECTIVE ACTION UNIT 536: AREA 3 RELEASE SITE, NEVADA TEST SITE, NEVADA}

Approved By: $\frac{\text { SIGNATURE APPROVED }}{\begin{array}{l}\text { Sabine Curtis, Acting Project Manager } \\ \text { Industrial Sites Project }\end{array}}$ Date: $\quad$ 8/23/05

Approved By: $\quad$ SIGNATURE APPROVED Date:

Janet Appenzeller-Wing, Acting Division Director

Environmental Restoration Division 
THIS PAGE INTENTIONALLY LEFT BLANK 


\section{TABLE OF CONTENTS}

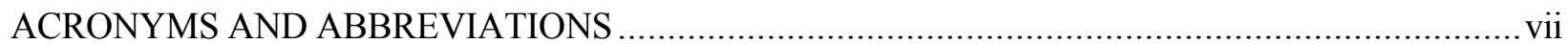

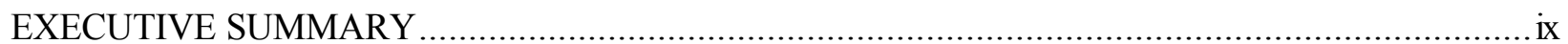

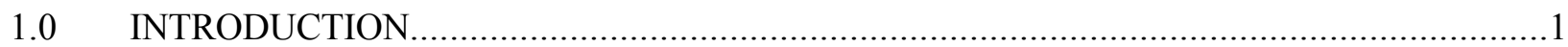

1.1 PURPOSE

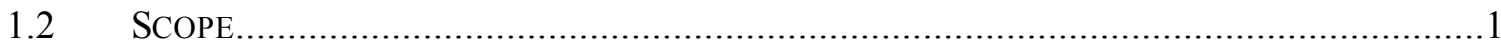

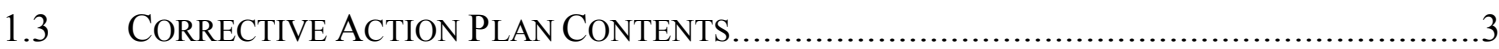

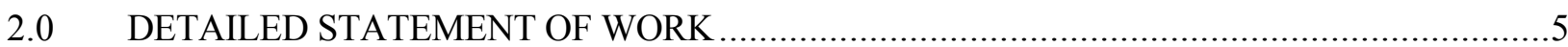

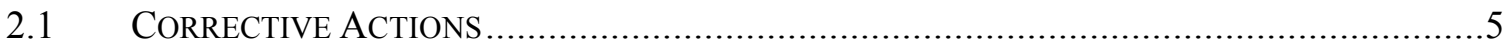

2.2 CONSTRUCTION QUALITY ASSURANCE / QUALITY CONTROL ......................................

2.2.1 Construction Field Sample Collection Activities ........................................... 9

2.2.2 Construction Laboratory/Analytical Data Quality Indicators.......................... 9

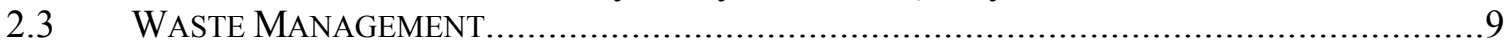

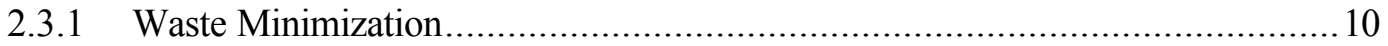

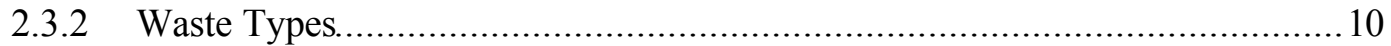

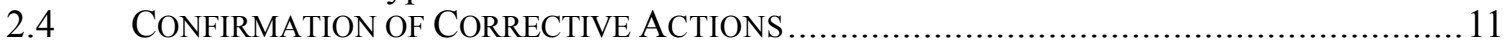

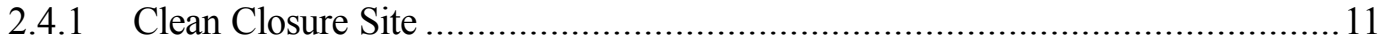

2.4.2 Laboratory/Analytical Data Quality Indicators..................................... 12

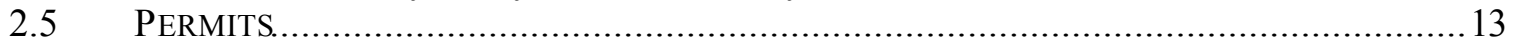

2.5.1 National Environmental Policy Act Checklist ........................................ 13

2.5.2 NNSA/NSO Real Estate/Operations Permit ............................................... 13

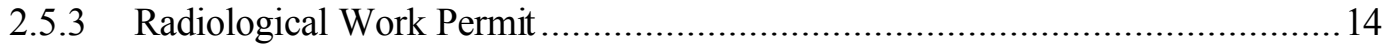

2.5.4 Excavation Permits and Blind Penetration Permits ................................... 14

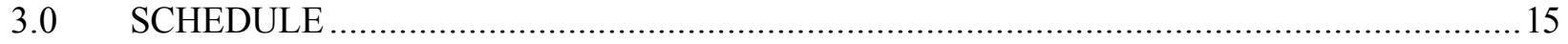

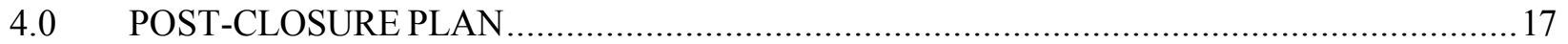

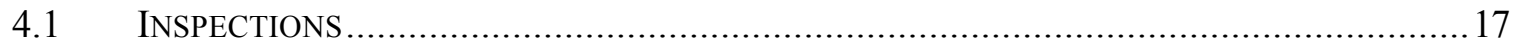

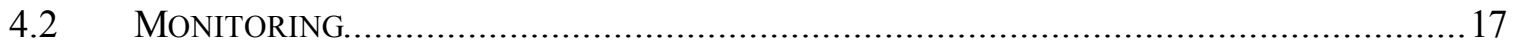

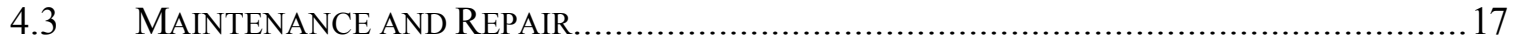

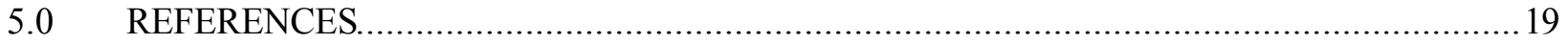

\section{TABLES}

TABle 1. CAS 03 44-02, SteAm Jenny Discharge CharacteriZATION RESUltS .................... 7

\section{FIGURES}

Figure 1. CAU 536 SITE LOCATION MAP..................................................................................... 2

FiguRE 2. CAS 03-44-02, STEAM JENNY DisCHARGE CHARACTERIZATION SAMPLE LOCATIONS.. 6 


\section{TABLE OF CONTENTS (continued)}

\section{APPENDICES}

APPENDIX A.1 Engineering Specifications and Drawings ..................................... A.1-1

APPENDIX A.2 Sampling and Analysis Plan .................................................... A.2-1

APPENDIX A.3 Project Organization ................................................................... A.3 1

LIBRARY DISTRIBUTION LIST 


\begin{tabular}{|c|c|}
\hline \multicolumn{2}{|c|}{ ACRONYMS AND ABBREVIATIONS } \\
\hline$\overline{b g s}$ & below ground surface \\
\hline $\mathrm{BN}$ & Bechtel Nevada \\
\hline CADD & Corrective Action Decision Document \\
\hline CAIP & Corrective Action Investigation Plan \\
\hline CAP & Corrective Action Plan \\
\hline CAS & Corrective Action Site(s) \\
\hline $\mathrm{CAU}$ & Corrective Action Unit(s) \\
\hline $\mathrm{COC}$ & contaminants of concern \\
\hline $\mathrm{CR}$ & Closure Report \\
\hline DOE & U.S. Department of Energy \\
\hline $\mathrm{DOE} / \mathrm{NV}$ & U.S. Department of Energy, Nevada Operations Office \\
\hline DQI & data quality indicator(s) \\
\hline DQO & Data Quality Objective(s) \\
\hline EPA & U.S. Environmental Protection Agency \\
\hline FFACO & Federal Facility Agreement and Consent Order \\
\hline $\mathrm{ft}$ & foot (feet) \\
\hline LLW & low-level waste \\
\hline NAC & Nevada Administrative Code \\
\hline NCRP & National Council on Radiation Protection and Measurements \\
\hline NDEP & Nevada Division of Environmental Protection \\
\hline NEPA & National Environmental Policy Act \\
\hline NNSA/NSO & U.S. Department of Energy, National Nuclear Security Administration \\
\hline & Nevada Site Office \\
\hline $\mathrm{NNSA} / \mathrm{NV}$ & U.S. Department of Energy, National Nuclear Security Administration \\
\hline & Nevada Operations Office \\
\hline NTS & Nevada Test Site \\
\hline OI & Organization Instruction(s) \\
\hline $\mathrm{OP}$ & Organization Procedure(s) \\
\hline $\mathrm{PAH}$ & polyaromatic hydrocarbon(s) \\
\hline PAL & preliminary action level(s) \\
\hline
\end{tabular}




\section{ACRONYMS AND ABBREVIATIONS (continued)}

$\begin{array}{ll}\mathrm{pCi} / \mathrm{g} & \text { picoCuries per gram } \\ \mathrm{PPE} & \text { personal protective equipment } \\ \mathrm{Pu} & \text { Plutonium } \\ \% \mathrm{R} & \text { percent recovery } \\ \mathrm{QA} / \mathrm{QC} & \text { quality assurance/quality control } \\ \mathrm{REOP} & \text { Real Estate/Operations Permit } \\ \mathrm{RPD} & \text { relative percent difference } \\ \mathrm{RWP} & \text { Radiological Work Permit(s) } \\ \mathrm{TPH} & \text { total petroleum hydrocarbon(s) } \\ \mathrm{WGS} & \text { Waste Generator Services } \\ \mathrm{yd}^{3} & \text { cubic yard(s) }\end{array}$




\section{EXECUTIVE SUMMARY}

Corrective Action Unit (CAU) 536, Area 3 Release Site is listed in the Federal Facility Agreement and Consent Order of 1996. CAU 536 is located in Area 3 of the Nevada Test Site, which is located approximately 65 miles northwest of Las Vegas, Nevada. CAU 536 consists of Corrective Action Site (CAS) 03-44-02, Steam Jenny Discharge.

CAS 03-44-02 was used for steam cleaning operations at the Area 3 Camp, and includes a large concrete pad, a sump located on the eastern side of the main pad, a smaller concrete pad adjacent to the western side of the larger pad, a drainage ditch running along the southern edge of the CAS footprint, and the surrounding soil.

Corrective action investigation activities for CAS 03-44-02 were performed from March through August 2004 according to the approved CAU 536 Corrective Action Investigation Plan (U.S. Department of Energy, National Nuclear Security Administration Nevada Site Office [NNSA/NSO], 2003). The results of the site investigation are reported in Appendix A of the approved CAU 536 Corrective Action Decision Document (CADD) (NNSA/NSO, 2004). According to the $\mathrm{CADD}$, the following contaminants of concern were found at concentrations above action levels:

- Total petroleum hydrocarbons (TPH) as diesel-range organics and oil-range organics

- Polyaromatic hydrocarbons (PAH) including Benzo(A)Pyrene, Benzo(A)Anthracene, Denzo(B)F luoranthene, Dibenzo(A,H)Anthracene, and Indeno(1,2,3-CD)Pyrene

- Plutonium $(\mathrm{Pu})-239$

TPH and PAH contamination was found to extend over the entire CAS footprint to a depth of 2 feet (ft) below ground surface (bgs). At an area surrounding the sump on the eastern side of the main pad, TPH and PAH contamination was found to extend to $6.5 \mathrm{ft} \mathrm{bgs}$, and at an area west of the main pad to $11 \mathrm{ft}$ bgs. Also, at two areas located south and west of the main pad Pu-239 contamination was found to $1 \mathrm{ft}$ bgs (NNSA/NSO, 2004).

As specified in the CAU 536 CADD, the recommended corrective action for CAS 03-44-02 is Clean Closure. To accomplish this, approximately 1,692 cubic yards $\left(\mathrm{yd}^{3}\right)$ of contaminated surface and subsurface soil being removed from various depths ranging from $0 \mathrm{ft}$ to $11 \mathrm{ft}$ bgs. The estimated volume includes a 25 percent expansion factor. The concrete pad will also be removed and will generate an approximate volume of $108 \mathrm{yd}^{3}$ of debris. Approximately $8 \mathrm{yd}^{3}$ of $\mathrm{Pu}-239$ contaminated soil will be removed, and managed as a separate waste stream. As a best management practice, any other associated features such as piping connecting the sumps will be identified and disposed appropriately. Soil verification samples will be collected from all excavations and analyzed for the appropriate contaminants of concern. After receiving analytical results verifying that clean up criteria have been met, all excavations will be backfilled with NTS native material, compacted by wheel rolling, and graded to the approximate surrounding site contours. 
Section: Executive Summary

Revision: 0

Date: September 2005

THIS PAGE INTENTIONALLY LEFT BLANK 


\subsection{INTRODUCTION}

Corrective Action Unit (CAU) 536, Area 3 Release Site is listed in the Federal Facility Agreement and Consent Order (FFACO) of 1996 (FFACO, 1996). CAU 536 is located in Area 3 of the Nevada Test Site (NTS), which is located approximately 65 miles northwest of Las Vegas, Nevada (Figure 1). CAU 536 is comprised of Corrective Action Site (CAS) 03-44-02, Steam Jenny Discharge (Figure 1).

Details of the site history are provided in Corrective Action Investigation Plan (CAIP) for CAU 536 (U.S. Department of Energy National Nuclear Security Administration Nevada Site Office [NNSA/NSO], 2003) and the Corrective Action Decision Document (CADD) for CAU 536 (NNSA/NSO, 2004).

\subsection{PURPOSE}

CAU 536 consists of CAS 03-44-02, Steam Jenny Discharge, located in Area 3 of the NTS. The site was characterized in 2004 according to the approved CAIP (NNSA/NSO, 2003) and the site characterization results are reported in the CAU 536 CADD (NNSA/NSO, 2004).

The purpose of this Corrective Action Plan (CAP) is to provide the detailed scope of work required to implement the recommended corrective actions as specified in the approved CAU 536 CADD (NNSA/NSO, 2004).

\subsection{SCOPE}

CAS 03-44-02, Steam Jenny Discharge, is located in the Area 3 Camp and consists of a large concrete pad, a sump located on the eastern side of the pad, a smaller concrete pad adjacent to the western side of the main pad, a drainage ditch running along the southern edge of the CAS, and the surrounding soil. Results of the site characterization found total petroleum hydrocarbons (TPH) as diesel-range organics and oil-range organics; polyaromatic hydrocarbons (PAH); and Plutonium (Pu) -239 as contaminants of concern (COC) present at concentrations greater than action levels (NNSA/NSO, 2004).

As stated in the CAU 536 CADD, the recommended corrective action for CAS 03-44-02 is clean closure (NNSA/NSO, 2004). This will be accomplished by removing contaminated soil from depths ranging from 2 feet $(\mathrm{ft})$ to $11 \mathrm{ft}$ below ground surface (bgs) from the CAS footprint. As a best management practice, the concrete pad will be demolished and any other associated features (e.g., piping connecting the sumps) will be identified, removed, and disposed appropriately. Soil samples will be collected from all excavations and analyzed for the appropriate COC to verify that clean up criteria have been met. All excavations will be backfilled with NTS native material, compacted, and graded to approximate surrounding contours. 
Date: September 2005

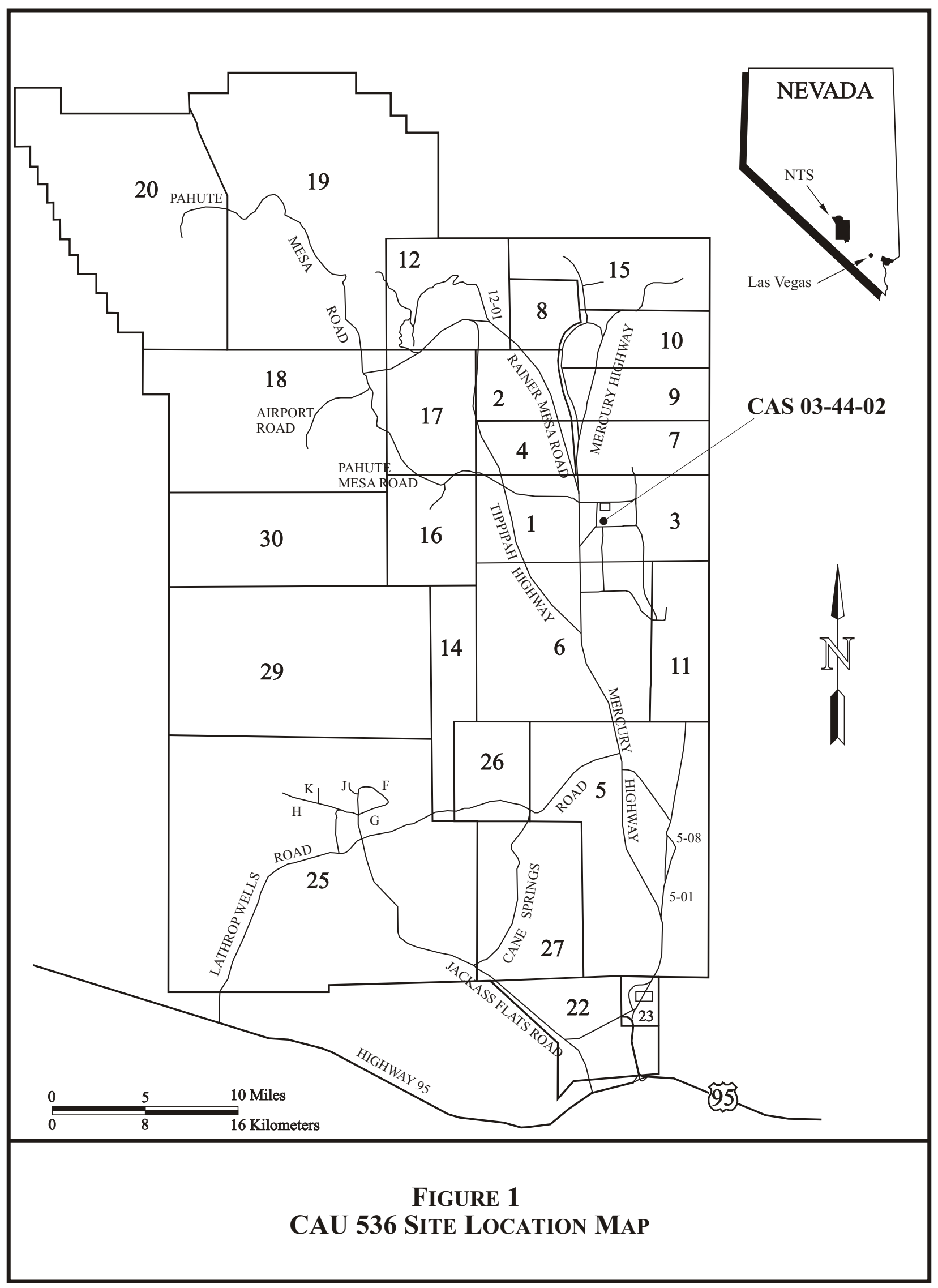




\section{Corrective ACtion Plan Contents}

This CAP is comprised of the following sections and appendices:

\begin{tabular}{ll} 
Section 1.0 & Introduction \\
Section 2.0 & Detailed Statement of Work \\
Section 3.0 & Schedule \\
Section 4.0 & Post-Closure Plan \\
Section 5.0 & References \\
Appendix A.1 & Engineering Specifications and Drawings \\
Appendix A.2 & Sampling and Analysis Plan \\
Appendix A.3 & Project Organization \\
\multicolumn{2}{l}{ Library Distribution List }
\end{tabular}

Appendix A.1 is included in the CAP as required by the approved FFACO CAP outline, but contains no material because engineering specification or drawings are not necessary for site closure. Similarly, Appendix A.2 is included as required but contains no material, because Sections 2.1 and 2.4 provide sufficient sampling detail.

This report was primarily developed using information and guidance from the following documents:

- Federal Facility Agreement and Consent Order (FFACO, 1996)

- Corrective Action Investigation Plan for Corrective Action Unit 536 (NNSA/NSO, 2003)

- Corrective Action Decision Document for Corrective Action Unit 536 (NNSA/NSO, 2004). 
Section: Introduction

Revision: 0

Date: September 2005

THIS PAGE INTENTIONALLY LEFT BLANK 


\subsection{DETAILED STATEMENT OF WORK}

The following three corrective action alternatives were evaluated for CAU 536 and identified in the CADD (NNSA/NSO, 2004):

Alternative 1 - No Further Action

Alternative 2 - Clean Closure

Alternative 3 - Close in Place with Administrative Controls

The recommended corrective action alternative is for CAS 03-44-02, Steam Jenny Discharge is Alternative 2 - Clean Closure.

\subsection{Corrective ACTIONS}

The recommended corrective action alternative for CAU 536 was identified in the CADD (NNSA/NSO, 2004) and approved by the Nevada Division of Environmental Protection (NDEP). The objective of the corrective actions is to prevent or mitigate adverse environmental impacts due to exposure and migration of surface and subsurface waste. The approved corrective action for CAS 03-44-02, Steam Jenny Discharge, is Clean Closure.

CAS 03-44-02 consists of a 70- by 40- $\mathrm{ft}$ concrete pad with a drain located in the center leading to a sump located at the eastern edge of the pad (Figure 2). A smaller concrete pad is located on the western edge of the main concrete pad. A drainage ditch and metal culvert are present south of the main concrete pad. The ditch diverts run-off from the Area 3 Camp to the U3du crater located $640 \mathrm{ft}$ east of the CAS. The site was used to steam clean equipment in the Area 3 Camp.

To clean close the site, an estimated 1,692 cubic yards $\left(\mathrm{yd}^{3}\right)$ (including a 25 percent expansion factor) of contaminated soil and $108 \mathrm{yd}^{3}$ of concrete debris will be removed and disposed at an appropriate disposal facility. Areas of contamination are shown in Figure 2. Site characterization sample locations and results are provided in Figure 2 and Table 1, respectively (NNSA/NSO, 2004). Because different COC are present in distinct areas of the site and because different waste streams need to be segregated, soil and concrete will be removed from the CAS in the following order:

1. The two $\mathrm{Pu}-239$ contaminated soil areas

2. The concrete pad

3. From the entire CAS footprint soil to a depth of $2 \mathrm{ft}$ bgs (Area 1, Figure 2)

4. The area surrounding the sump soil to a depth of $6.5 \mathrm{ft}$ bgs (Area 2, Figure 2)

5. The area located to the west of the former concrete pad soil to a depth of $11 \mathrm{ft} \mathrm{bgs}$ (Area 3, Figure 2) 


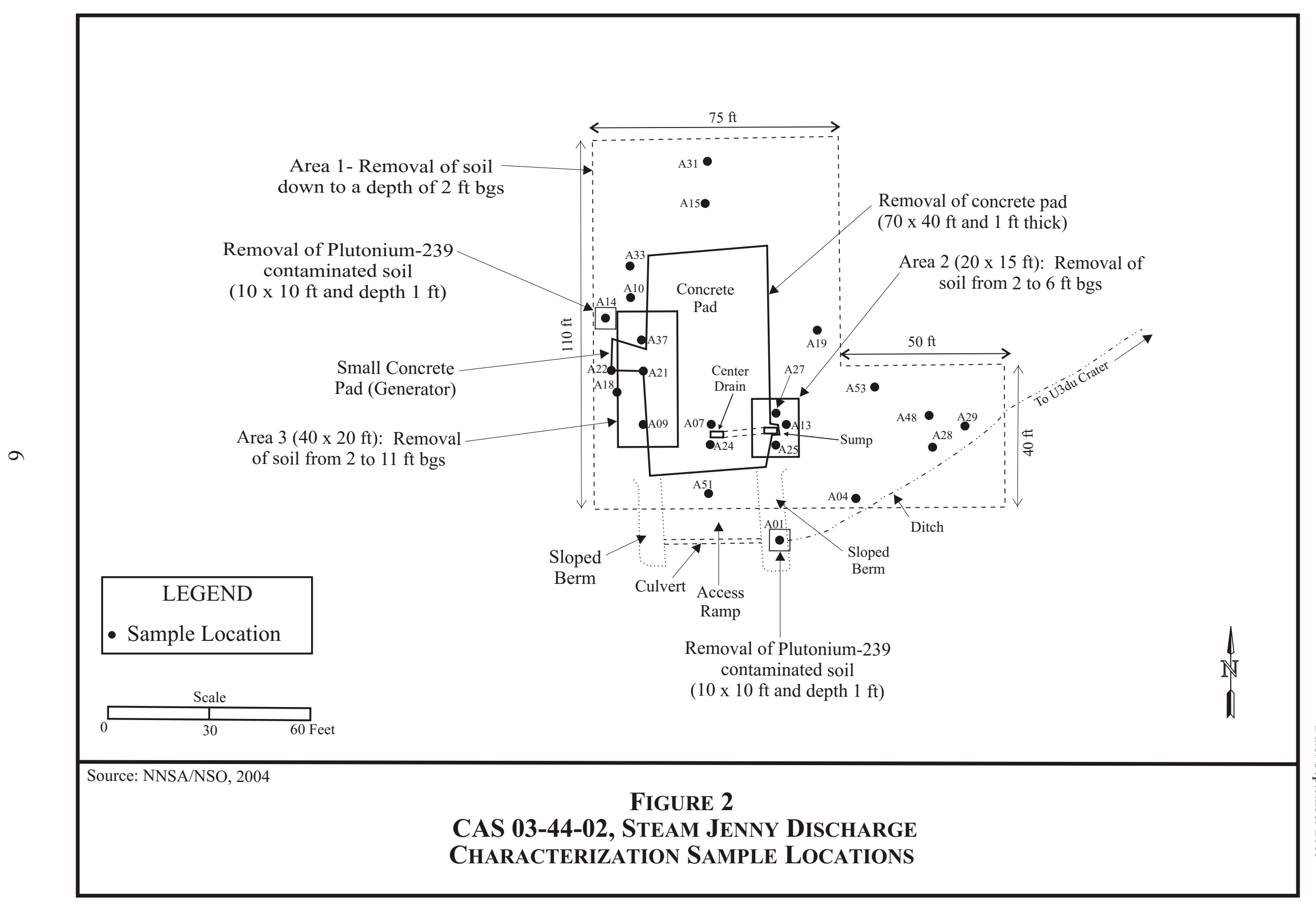


TABLE 1. CAS 03 44-02, STEAM JeNNY DisChARGE

CHARACTERIZATION RESUlTS

\begin{tabular}{|c|c|c|c|c|c|c|c|c|c|}
\hline $\begin{array}{c}\text { Sample } \\
\text { Location }\end{array}$ & $\begin{array}{c}\text { Sample } \\
\text { Number }\end{array}$ & $\begin{array}{c}\begin{array}{c}\text { Depth } \\
\text { (ft) }\end{array} \\
\end{array}$ & $\begin{array}{c}\text { TPH } \\
\text { (ppm) }\end{array}$ & $\begin{array}{l}\text { BAA } \\
\text { (ppb) }\end{array}$ & $\begin{array}{l}\text { BAP } \\
\text { (ppb) }\end{array}$ & $\begin{array}{l}\text { BBF } \\
\text { (ppb) }\end{array}$ & $\begin{array}{c}\text { DiB } \\
\text { (ppb) }\end{array}$ & $\begin{array}{l}\text { Ind } \\
\text { (ppb) }\end{array}$ & $\begin{array}{l}\mathrm{Pu}-239 \\
(\mathrm{pCi} / \mathrm{g})\end{array}$ \\
\hline PAL & & & 100 & 2,100 & 210 & 2,100 & 210 & 2,100 & 12.7 \\
\hline$\overline{\mathrm{A} 01}$ & 536A001 & $0-0.5$ & - & - & - & - & - & - & 15.1 \\
\hline A04 & 536A004 & $0-0.5$ & 340 & - & - & - & - & - & - \\
\hline $\mathrm{A} 07$ & 536A014 & $1.0-1.5$ & 1,000 & - & $1,100(\mathrm{~J})$ & - & - & - & - \\
\hline \multirow[t]{4}{*}{ A09 } & $536 \mathrm{~A} 023$ & $1.0-2.0$ & 230 & 3,400 & $3,200(\mathrm{~J})$ & $\begin{array}{c}4,900 \\
(\mathrm{~J})\end{array}$ & $\begin{array}{l}450 \\
(J)\end{array}$ & - & - \\
\hline & 536A024 & $4.5-5.5$ & 440 & - & - & - & - & - & - \\
\hline & 536A045 & $10.0-11.0$ & - & - & $330(\mathrm{~J})$ & - & - & - & - \\
\hline & 536A046 & $10.0-11.0$ & - & - & $280(\mathrm{~J})$ & - & - & - & - \\
\hline A10 & $536 \mathrm{~A} 026$ & $1.0-2.0$ & - & 3,500 & 2,700 & 4,100 & $\begin{array}{l}340 \\
(J)\end{array}$ & - & - \\
\hline A13 & 536A022 & $0-0.5$ & 240 & - & - & - & - & - & - \\
\hline A14 & 536A039 & $0-1.0$ & - & - & $240(\mathrm{~J})$ & - & - & - & 16.9 \\
\hline A15 & 536A042 & $0.0-0.5$ & 120 & - & - & - & - & - & - \\
\hline A18 & $536 \mathrm{~A} 054$ & $0-0.05$ & 180 & - & - & - & - & - & - \\
\hline A19 & 536A057 & $0-0.05$ & - & - & $250(\mathrm{~J})$ & - & - & - & - \\
\hline \multirow[t]{2}{*}{ A21 } & $536 \mathrm{~A} 063$ & $0.5-1.5$ & 190 & - & - & - & - & - & - \\
\hline & $536 \mathrm{~A} 065$ & $7.0-8.0$ & - & - & $240(\mathrm{~J})$ & - & - & - & - \\
\hline A22 & 536A066 & $0.5-1.5$ & 340 & 4,200 & $3,100(\mathrm{~J})$ & $\begin{array}{c}6,100 \\
(\mathrm{~J})\end{array}$ & $\begin{array}{l}560 \\
(J)\end{array}$ & 2,400 & \\
\hline A24 & $536 \mathrm{~A} 101$ & $0-1.0$ & 500 & - & $320(\mathrm{~J})$ & - & - & - & - \\
\hline $\mathrm{A} 25$ & 536A104 & $4.5-5.0$ & 140 & - & $860(\mathrm{~J})$ & - & - & - & - \\
\hline \multirow[t]{2}{*}{ A27 } & 536A107 & $0-1.0$ & - & - & $260(\mathrm{~J})$ & - & - & - & - \\
\hline & 536A108 & $4.5-5.0$ & 110 & 9,800 & $7,400(\mathrm{~J})$ & $\begin{array}{c}11,000 \\
(\mathrm{~J})\end{array}$ & - & $\begin{array}{c}5,600 \\
(\mathrm{~J})\end{array}$ & - \\
\hline A28 & 536A109 & $0-0.5$ & 110 & - & - & - & - & - & - \\
\hline A29 & 536A110 & $0-0.5$ & 190 & - & - & - & - & - & - \\
\hline A31 & 536A113 & $0-1.0$ & 770 & - & - & - & - & - & - \\
\hline A33 & 536A117 & $0.5-1.5$ & 1,800 & - & $330(\mathrm{~J})$ & - & - & - & - \\
\hline \multirow[t]{2}{*}{ A37 } & $536 \mathrm{~A} 125$ & $0.5-1.5$ & 150 & - & - & - & - & - & - \\
\hline & 536A126 & $4.0-5.0$ & 2,500 & - & - & - & - & - & - \\
\hline A48 & 536A145 & $0-1.0$ & 920 & - & $1,100(\mathrm{~J})$ & - & - & - & - \\
\hline A51 & 536A149 & $1.0-2.0$ & - & - & $280(\mathrm{~J})$ & - & - & - & - \\
\hline A53 & 536A152 & $0-0.5$ & 460 & $11,000(\mathrm{~J})$ & $11,000(\mathrm{~J})$ & $\begin{array}{c}15,000 \\
(\mathrm{~J})\end{array}$ & - & $\begin{array}{c}9,200 \\
(\mathrm{~J})\end{array}$ & - \\
\hline
\end{tabular}

\section{NOTES :}

TPH - Total petroleum hydrocarbons

BAP - Benzo(A)Pyrene

BAA - Benzo(A)Anthracene

BBF - Benzo(B)Fluoranthene

DiB - Dibenzo(A,H)Anthracene

Ind - Indeno(1,2,3-CD)Pyrene
$\mathrm{J}=$ Estimate Value

PAL $=$ Preliminary Action Level

$\mathrm{Pu}-239$ = Plutonium-239

- = Analyte not detected

Source: NNSA/NSO, 2004 


\section{Plutonium Are as}

Characterization results for soil samples collected at locations A01 and A14 (see Figure 2) indicated $\mathrm{Pu}-239$ is present at concentrations (Table 1) above the preliminary action level (PAL) of 12.7 picoC uries per gram (pCi/g) (NDEP, 2004; National Council on Radiation Protection and Measurements [NCRP], 1999). Radiologically contaminated soil from both sample locations will be removed from a 10-by-10 ft area to a depth of approximately $1 \mathrm{ft}$ bgs for an estimated total volume of approximately $8 \mathrm{yd}^{3}$. During excavation, radiological surveys will be performed to determine radioactivity levels. Radiological surveys will be conducted in accordance with the Bechtel Nevada (BN) Company Directives, Radiological Operations, Organization Instructions (OI), and Organization Procedures (OP). After the estimated volume of soil has been removed, a minimum of three soil verification samples will be taken from each excavated area. Samples will be analyzed for isotopic $\mathrm{Pu}$ to verify that cleanup criteria have been met. Contaminated soil will be containerized and managed appropriately. BN Waste Generator Services (WGS) will develop a waste profile for disposal using radiological data from the CADD and/or if necessary by collecting and analyzing waste characterization samples.

\section{Concrete Pad}

According to the CADD, the concrete pad is not contaminated, but the soil beneath the pad is contaminated with TPH and PAHs (NNSA/NSO, 2004). The CADD states that small pieces of asphalt were observed in the soil and this may be the source of PAHs (NNSA/NSO, 2004). To access the soil beneath the pad, the concrete pad will be demolished and the debris removed, using appropriate equipment. Approximately $108 \mathrm{yd}^{3}$ of debris will be generated. The concrete debris will be staged or placed in appropriate containers and radiologically surveyed for unrestricted free release. If the debris does not meet the free release criteria, a waste disposal profile will be developed and the waste appropriately disposed.

\section{Area 1}

Characterization results indicate that TPH and PAH exceeding the PALs (Nevada Administrative Code [NAC], 2003; U.S. Environmental Protection Agency [EPA], 2002a) are present in soil down to a depth of $2 \mathrm{ft}$ bgs across most of the CAS footprint (Figure 2) (NNSA/NSO, 2004). Soil will be removed to a depth of $2 \mathrm{ft}$ bgs. Excavated soil will be placed on plastic or directly into trucks. During excavation, field screening for TPH will be performed using PetroFLAG ${ }^{\circledR}$ kits or equivalent. After field screening indicates that TPH contamination is no longer present above the PAL, a sampling grid with $10 \mathrm{ft}$ spacing will be established over the excavated area. A minimum of one soil verification sample will be collected from the center of each 10- $\mathrm{ft}$ grid square and submitted for TPH and PAH analysis to verify that soil contamination has been removed and the remaining soil contains no contaminants above the PALs.

\section{Area 2}

Characterization results for sample locations A25 and A27 indicate that TPH and PAH exceeding the PALs (EPA, 2002a; NAC, 2003) are present down to a depth of $6 \mathrm{ft}$ bgs (Figure 2) (NNSA/NSO, 2004). Since soil up to a depth of $2 \mathrm{ft}$ bgs will be removed as part of Area 1 clean up, additional soil will be removed from a depth of 2 to $6 \mathrm{ft}$ bgs. Excavated soil will be placed on plastic or directly into trucks. During excavation, field screening for TPH will be performed using PetroFLAG ${ }^{\circledR}$ kits or equivalent. The area will be divided into 10 - $\mathrm{ft}$ grid sections. After field screening indicates that contamination is no longer present above PALs, a minimum of one soil verification sample from each side wall and two from the base of the excavation will be 
collected. The samples will be analyzed for TPH and PAH to verify that soil contamination has been removed, and the remaining soil contains no contaminants above the PALs.

As a best management practice, any other associated features, such as metal piping connecting the sumps, will be identified, removed, and disposed appropriately.

\section{Area 3}

Characterization results for sample locations A09 and A21 indicate that TPH and PAH exceeding the PALs (EPA, 2002a and NAC, 2003) are present down to a depth of $11 \mathrm{ft} \mathrm{bgs}$ and that TPH exceeding the PAL is present at sample location A37 (NNSA/NSO, 2004). The approximate area of contamination is shown in Figure 2. Because $2 \mathrm{ft}$ of soil will be removed as part of Area 1 clean up, additional soil will be removed from a depth of 2 to $11 \mathrm{ft}$ bgs. Excavated soil will be placed on plastic or directly into trucks. During excavation, field screening for TPH will be performed using PetroFLAG ${ }^{\circledR}$ kits or equivalent. After the soil is removed, the area will be divided into 10- $\mathrm{ft}$ grid sections. After field screening indicates that TPH contamination is no longer present above the PAL, a sampling grid with 10 - $\mathrm{ft}$ spacing will be established over the excavated area. A minimum of one soil verification sample will be collected from the center of each 10- $\mathrm{ft}$ grid square and submitted for TPH and PAH analysis to verify that soil contamination has been removed, and the remaining soil contains no contaminants above the PALs.

After analytical results verify no contamination remains on site, all excavated areas will be backfilled with NTS native fill from a clean borrow source and graded to the approximate surrounding grade.

\subsection{CONSTRUCTION Quality ASSURANCE / Quality CONTROL}

Construction activities are limited to excavation and recontouring. No engineered structures will be constructed as part of site closure. Therefore, a construction quality assurance/quality control (QA/QC) plan will not be required.

\subsubsection{Construction Field Sample Collection Activities}

Construction field samples are not necessary for closure activities, although samples may be collected for the purpose of waste stream characterization and to verify that cleanup levels have been met. Field sample collection activities are addressed in Sections 2.1 and 2.4.

\subsubsection{Construction Laboratory/Analytical Data Quality Indicators}

CAU 536 closure activities are limited to excavation and recontouring. Therefore, a construction QA/QC plan is not required, and construction data quality indicators (DQI) are not applicable. To ensure that backfill material remains consistent, all fill will be taken from an approved NTS borrow source.

\subsection{WASTE MANAGEMENT}

All waste streams will be managed and disposed of in accordance with applicable state and federal regulations, U.S. Department of Energy (DOE) Orders, U.S. Department of Transportation, and BN waste management procedures. CAU 536 closure activities are expected 
to generate sanitary waste/construction debris, low-level waste (LLW), and hydrocarbon waste. Waste generated during closure activities will be properly managed and shipped to appropriate onsite or offsite facilities. Confirmation of waste disposal will be included in the CAU 536 Closure Report (CR). BN WGS personnel will create a waste profile for all LLW. Waste classification sample data from the CADD will be provided to the Solid Waste Operations group for disposal of hydrocarbon waste to an appropriate onsite disposal facility once the waste meets the waste acceptance criteria.

\subsubsection{Waste Minimization}

All work activities that generate waste will follow the BN Waste Minimization and Pollution Prevention Program. Special care will be given to properly characterize and segregate the waste streams to avoid the generation of additional waste.

\subsubsection{Waste Types}

\section{Sanitary Waste}

Sanitary waste (e.g., non-impacted personal protective equipment [PPE] and general trash) and construction debris (e.g., wood, concrete, metal, plastic) removed from the site will be radiologically screened for free release (U.S. Department of Energy, Nevada Operations Office [DOE/NV], 2000) and disposal. Sanitary waste will be disposed of in an onsite permitted landfill.

\section{Low-Level Radioactive Waste}

Closure activities may include removal of radiologically contaminated soil with PAH. The waste will be characterized by process knowledge, laboratory analysis, and/or radiological screening; then a waste profile for disposal will be prepared. Based on radioactivity levels, the waste may be classified as hydrocarbon waste or LLW. If LLW is generated, it will be stored in a radioactive materials area and packaged in approved containers, if required. After approval of the waste profile, the LLW will then be transported to an appropriate onsite disposal facility and disposed. All LLW shall be managed and disposed in accordance with BN OP-2151.304, "Radioactive Waste Tracking, Handling, and Management at the NTS" (BN, 2004a), and all applicable state and federal regulations. All LLW will be packaged in the presence of a Waste Certification Official and WGS personnel according to OP-2151.304 (BN, 2004a). LLW will be stored in a radioactive materials area until transport to an appropriate disposal facility can be arranged.

\section{Hydrocarbon Waste}

Waste classification samples from the CADD will be utilized in order to satisfy the landfill waste acceptance criteria for hydrocarbon waste. All hydrocarbon waste meeting the land disposal restrictions as specified in the landfill permit will be disposed in the NTS Area 6 Hydrocarbon Landfill. Hydrocarbon waste not meeting the landfill disposal restrictions will be stored in a waste accumulation area until a disposal path is identified.

\section{Decontamination Waste}

All radiologically impacted equipment will be surveyed prior to release from the exclusion zone. Any equipment that becomes contaminated during closure activities will be decontaminated on site. Dry decontamination will be the preferred method. For larger pieces of equipment that 
cannot be effectively decontaminated using dry decontamination techniques, wet decontamination techniques shall be used. All decontamination rinsate will be managed appropriately in accordance with all applicable regulations and once characterized, properly disposed.

\section{Personal Protective Equipment}

All PPE that becomes contaminated during closure activities shall be disposed with the appropriate waste stream. All wastes generated during closure activities will be properly disposed in either onsite landfills or at a permitted offsite treatment, storage, and disposal facility.

\subsection{CONFIRMATION OF CORRECTIVE ACTIONS}

Accurate and defensible analytical data will be collected to characterize waste and verify that the closure objectives outlined in this CAP have been met.

\subsubsection{Clean Closure Site}

Section 2.1 provides information on verification samples required for CAS 03-44-02, Steam Jenny Discharge. The site will be considered clean closed after laboratory results verify that any contaminants remaining in verification samples are below the applicable action levels. In addition, removal of materials will be confirmed by visual inspection and photographic documentation of final site conditions.

\section{Sample Collection Methods}

All samples will be collected by qualified BN Environmental Restoration personnel. Samples will be collected by hand, using disposable pre-cleaned or decontaminated sampling equipment (BN, 2000a). Samples will be collected either by hand from the indicated locations, or if the excavation poses a safety hazard to sampling personnel, from the center of a backhoe bucket of soil collected from the indicated locations. Sample collection date, time, and other pertinent information will be logged on a chain of custody form and in a bound field notebook. Sample traceability is established by completing a BN Service Request and Chain of Custody Record form and submitting with all samples.

All samples will be collected in clean containers, labeled appropriately, sealed with a tamperproof seal, bagged, placed on ice in a cooler, and transported to the BN Environmental Technical Services group under a BN "Sample Chain of Custody" form (BN, 2000b). BN Environmental Technical Services will be responsible for sample management and shipment of the samples to an approved offsite laboratory for analysis. Samples will be analyzed by EPA-approved analytical methods at EPA-approved laboratories (EPA, 1996). Sample analysis will include laboratory analysis of QA/QC samples and will follow stringent QA/QC procedures (EPA, 1996). Sample analysis for isotopic plutonium will be performed in accordance with Environmental Measurements Laboratory Procedures Manual (DOE, 1997).

All samples will be labeled with a unique sample identification number using the CAS number followed by the sample number (e.g., 034402-V1). Waste characterization samples will be named by using the CAS number followed by sample number (e.g., 034402-WC1). 
One set of QA/QC samples will be collected for every 20 environmental samples. QA/QC samples will include blind duplicates and matrix spike/matrix spike duplicates. The blind duplicate will be labeled with a unique sample number.

\subsubsection{Laboratory/Analytical Data Quality Indicators}

Data Quality Objectives (DQO) are qualitative and quantitative statements that specify the quality of the data required to support closure of a site. The DQO for the CAU 536 site investigation were defined in the CAIP (NNSA/NSO, 2003) using the Seven Step DQO Process developed by the EPA(EPA, 2000). Two conceptual site models for the CAU 536 CAS were defined in the CAIP (NNSA/NSO, 2003), and these models were reconciled with the results of the site investigation in the CADD (NNSA/NSO, 2004). (See Appendix A of the CADD.)

Sample analytical results will be generated during closure activities for CAS 03-44-02, Steam Jenny Discharge. The CAS will be clean closed and will require the collection and analysis of verification soil samples. All laboratory data generated during closure activities will be reviewed by project personnel to ensure the data are usable and complete according to the CAU 536 DQO. In addition, as specified in the Industrial Sites Quality Assurance Project Plan (U.S. Department of Energy, National Nuclear Security Administration Nevada Operations Office [NNSA/NV], 2002), 100 percent of the final data packages for verification samples will be evaluated at the Tier I and Tier II levels using the applicable BN OIs and OPs. These include OI-2151.303 (BN, 2004b) for validating radiological data, and OI-2154.459 (BN, 2003) for validating inorganic chemical data. OI-2154.459 is based on EPA Functional Guidelines (EPA, 2002b). Any data determined not to be valid will be identified in the CR. More details on the proposed number and location of the verification samples are given in Section 2.1 of this plan.

DQI are qualitative and quantitative statements that specify the data requirements of a project. The DQI include accuracy, precision, comparability, completeness, representativeness, and sensitivity. These DQI are discussed below.

\section{Precision}

Precision is a measure of agreement among a replicate set of measurements of the same property under similar conditions. This agreement is expressed as the relative percentage difference (RPD) between duplicate measurements (EPA, 1996) Precision applies to parameters sampled and analyzed in duplicate.

One duplicate sample will be collected per set of 20 or fewer verification samples. All duplicate samples will be collected from the same medium and analyzed for the same set of analytes as verification samples. The precision of the analytical results will be assessed by calculating the RPD for a verification sample and its duplicate sample results. An RPD of less than or equal to 30 percent indicates acceptable precision (NNSA/NV, 2002).

\section{Accuracy/Bias}

Accuracy is a measure of the closeness of an individual measurement or the average of a number of measurements to the true value. Accuracy includes a combination of random error (precision) and systematic error (bias) components that result from sampling and analytical operations. This closeness is represented as percent recovery (\%R) (EPA, 1996). Accuracy will be assessed by 
examining the $\% \mathrm{R}$ of laboratory control and spiked samples. A $\% \mathrm{R}$ within the range of 70-130 percent indicates satisfactory analytical accuracy (NNSA/NV, 2002).

\section{Representativeness}

Representativeness is a qualitative evaluation of measurement system performance. It is the degree to which sample data accurately and precisely represents a characteristic of a population, parameter variations at a sampling point, or an environmental condition (EPA, 1996).

Representativeness will be attained by ensuring that the sample locations, analytical parameters, analytical methods, sampling protocols, and sample handling all meet the project-specific objectives.

\section{Comparability}

Comparability is a qualitative measure that expresses the confidence that one data set can be compared to another. It will be achieved by using standardized field sampling procedures and the same analytical methods for sample analysis. Sample results will be reported in standard units to allow for comparison of the data.

\section{Completeness}

Completeness is a quantitative measure of data quality expressed as the percentage of valid data obtained that satisfies the project-specific requirements. Since a limited number of samples will be collected for both waste characterization and verification of closure, 100 percent of the data collected needs to be of acceptable quality to maintain acceptable QA/QC standards.

\section{Sensitivity}

Sensitivity is the capability of a method or instrument to discriminate between measurement responses representing different levels of a variable of interest. This indicator is determined from the value of the standard deviation at the concentration level of interest. It represents the minimum difference of concentration that can be distinguished between two samples with a high degree of confidence. Sensitivity must be sufficient to detect contaminants at or below decision levels. Sensitivity will be achieved by analyzing all samples using appropriate EPA-approved analytical laboratories, methods, and instruments.

\subsection{PERMiTs}

Prior to beginning field closure activities, planning documents and permits will be prepared. These documents will include a Field Management Plan, National Environmental Protection Agency (NEPA) Checklist, NNSA/NSO Real Estate/Operations Permit (REOP), Radiological Work Permit (RWP), BN Work Packages, excavation permits, and blind penetration permits.

\subsubsection{National Environmental Policy Act Checklist}

A NEPA Checklist will be completed prior to all excavation activities at the site. Excavation activities will follow all applicable federal, state, and local laws, regulations, and permits regarding protection of the environment.

\subsubsection{NNSA/NSO Real Estate/Operations Permit}

A REOP will be obtained prior to beginning closure activities. The REOP will establish the NNSA/NSO as the prime authority possessing control of the site. 


\subsubsection{Radiological Work Permit}

RWPs will be required for work at any radiologically impacted site when radiological conditions require, as determined by the BN Health Physics. RWPs will inform workers of the specific PPE necessary to protect them while performing the ir tasks and identify site-specific controls. The workers will be required to sign the permits and acknowledge their understanding of the requirements before entry into any contamination area, if present. The RWPs will be maintained by the Radiological Control Technician at the entrance to the contamination area. All site workers will be required to be Radiation Worker II trained to perform any work within a radiologically controlled area.

\subsubsection{Excavation Permits and Blind Penetration Permits}

An excavation permit and a blind penetration permit will be obtained prior to beginning any excavation activities. These permits require that a utility clearance will also be performed. A copy of the permit will be filed on site throughout the duration of the project. 


\subsection{SCHEDULE}

All preparation and field activities are scheduled for completion in Fiscal Year 2006. The FFACO deadline for the CR has not yet been established. Sufficient flexibility has been incorporated into the field schedule to allow for minor difficulties (e.g., weather, equipment failure). The NNSA/NSO shall notify the NDEP of any condition or event that may impact the project schedule. 
Date: September 2005

THIS PAGE INTENTIONALLY LEFT BLANK 


\subsection{POST-CLOSURE PLAN}

CAU 536 will be clean closed; therefore, no post-clo sure site inspections or monitoring are required.

\subsection{INSPECTIONS}

CAU 536 will be clean closed; therefore, no post-closure inspection will be required.

\subsection{MONITORING}

No post-closure data will be collected for CAU 536; therefore, no post-closure monitoring is required for this CAS.

\subsection{MAINTENANCE AND REPAIR}

CAU 536 will be clean closed; therefore, no post-closure maintenance or repairs will be required. 
Date: September 2005

THIS PAGE INTENTIONALLY LEFT BLANK 


\subsection{REFERENCES}

BN, see Bechtel Nevada.

Bechtel Nevada. 2000a. “Soil Sampling,” Organization Instruction OI-2152.108. Las Vegas, NV.

Bechtel Nevada. 2000b. "Sample Chain of Custody,” OI-2152.100. Las Vegas, NV.

Bechtel Nevada. 2003. "Inorganic Data Verification and Validation," OI-2154.459. Las Vegas, NV.

Bechtel Nevada. 2004a. "Radiological Waste Tracking, Handling, and Management at the NTS," Organization Procedure OP-2151.304, Revision 5. Las Vegas, NV.

Bechtel Nevada. 2004b. "Validation of Radiological and Chemical Laboratory Data," OI-2151.303. Las Vegas, NV.

DOE, see U.S. Department of Energy

DOE/NV, see U.S. Department of Energy/Nevada Operations Office

EPA, see U.S. Environmental Protection Agency.

FFACO, see Federal Facility Agreement and Consent Order.

Federal Facility Agreement and Consent Order. 1996 (as amended). Agreed to by the State of Nevada, the U.S. Department of Energy, and the U.S. Department of Defense.

NAC, see Nevada Administrative Code.

Nevada Administrative Code. 2003. NAC 445A.2272, “Contamination of Soil: Establishment of Action Level." Carson City, NV.

NCRP, see National Council on Radiation Protection and Measurements.

NDEP, see Nevada Division of Environmental Protection.

National Council on Radiation Protection and Measurements. 1999. Recommended Screening Limits for Contaminated Surface Soil and Review of Factors Relevant to Site-Specific Studies, NCRP Report Number 129. Bethesda, MD. 


\section{REFERENCES (continued)}

Nevada Division of Environmental Protection. 2004. Review of Industrial Sites Project Document "Calculating Industrial Sites Project Remediation Goals for Radionuclides in Soil Using the Residual Radiation (RESRAD) Computer Code." Letter from Tim Murphy (Chief for the Bureau of Federal Facilities) to Robert Bangerter (Acting Director Environmental Restoration Division) dated November 19 Las Vegas, NV.

NNSA/NSO, see U.S. Department of Energy, National Nuclear Security Administration Nevada Site Office.

NNSA/NV, see U.S. Department of Energy, National Nuclear Security Administration Nevada Operations Office

U.S. Department of Energy. 1997. Environmental Measurements Laboratory Procedures Manual, HASL-300, $28^{\text {th }}$ Ed., Vol. 1. New York, NY.

U.S. Department of Energy, National Nuclear Security Administration Nevada Operations Office. 2002. Industrial Sites Quality Assurance Project Plan, Nevada Test Site, Nevada, Rev. 3, DOE/NV--372-REV. 3. Las Vegas, NV.

U.S. Department of Energy, National Nuclear Security Administration Nevada Site Office. 2003. Corrective Action Investigation Plan for Corrective Action Unit 536: Area 3 Release Site, Nevada Test Site, Nevada, Rev. 0, DOE/NV-900, Revision 0. Las Vegas, NV.

U.S. Department of Energy, National Nuclear Security Administration Nevada Site Office. 2004. Corrective Action Decision Document for Corrective Action Unit 536: Area 3 Release Site, Nevada Test Site, Nevada, Rev. 0, DOE/NV-1021, Revision 0. Las Vegas, NV.

U.S. Department of Energy, Nevada Operations Office. 2000. NV/YMP Radiological Control Manual, Rev. 4, DOE/NV/11718-079. Las Vegas, NV.

U.S. Environmental Protection Agency. 1996. Test Methods for Evaluating Solid Waste Physical/Chemical Methods, SW-846, Third Edition. Washington, D.C.

U.S. Environmental Protection Agency. 2000. Guidance for Data Quality Assessment: Practical Methods for Data Analysis, EPA QA/G-9, EPA/600/R-96/055. Washington, D.C.

U.S. Environmental Protection Agency. 2002a. Region 9 Preliminary Remediation Goals, October. San Francisco, CA.

U.S. Environmental Protection Agency. 2002b. Contract Laboratory Program National Functional Guidelines for Inorganic Data Review, EPA/540/R-94/013. Washington, D.C. 


\section{APPENDIX A.1}

\section{ENGINEERING SPECIFICATIONS AND DRAWINGS}

NOTE: Engineering specifications and drawings are not required for closure of Corrective Action Unit 536. This Appendix is included here as required by the approved Federal Facility Agreement and Consent Order outline for a Corrective Action Plan 
Section: Appendix A.1

Revision: 0

Date: September 2005

THIS PAGE INTENTIONALLY LEFT BLANK

A.1-2 


\section{APPENDIX A.2}

\section{SAMPLING AND ANALYSIS PLAN}

NOTE: Sufficient details on the type, number, and location of verification samples to be collected to verify site closure activities have been provided in Sections 2.1 and 2.4. This Appendix is included here as required by the approved Federal Facility Agreement and Consent Order outline for a Corrective Action Plan 
Section: Appendix A.2

Revision: 0

Date: September 2005

\section{THIS PAGE INTENTIONALLY LEFT BLANK}

A.2-2 


\section{PROJECT ORGANIZATION}


Section: Appendix A.3

Revision: 0

Date: September 2005

THIS PAGE INTENTIONALLY LEFT BLANK

A.3-2 


\section{PROJECT ORGANIZATION}

The U.S. Department of Energy, National Nuclear Security Administration Nevada Site Office (NNSA/NSO) points of contact for this project are as follows:

NNSA/NSO Acting Project Manager: Sabine Curtis

Telephone Number: (702) 295-0542

NNSA/NSO Task Manager: Sabine Curtis

Telephone Number: (702) 295-0542

The identification of the project Health and Safety Officer and the Quality Assurance Officer can be found in the appropriate plan. However, personnel are subject to change and it is suggested that the appropriate U.S. Department of Energy Project Manager be contacted for further information. The Task Manager will be identified in the Federal Facility Agreement and Consent Order Monthly Activity Report prior to the start of field activities. 
Section: Appendix A.3

Revision: 0

Date: September 2005

THIS PAGE INTENTIONALLY LEFT BLANK 
Section: Library Distribution

Revision: 0

Date: September 2005

\section{LIBRARY DISTRIBUTION LIST}


Section: Library Distribution

Revision: 0

Date: September 2005

THIS PAGE INTENTIONALLY LEFT BLANK 


\section{LIBRARY DISTRIBUTION LIST}

U.S. Department of Energy 1 (Uncontrolled)

National Nuclear Security Administration

Nevada Site Office

Technical Library

P.O. Box $98518, \mathrm{M} / \mathrm{S} 505$

Las Vegas, NV 89193-8518

U.S. Department of Energy

1 (Uncontrolled, electronic copy)

Office of Scientific and Technical Information

P.O. Box 62

Oak Ridge, TN 37831-0062

Southern Nevada Public Reading Facility

c/o Nuclear Testing Archive

P.O. Box 98521, M/S 400

Las Vegas, NV 89193-8521

Manager, Northern Nevada FFACO

Public Reading Facility

c/o Nevada State Library \& Archives

Carson City, NV 89701-4285

2 (Uncontrolled, electronic copies)

1 (Uncontrolled, electronic copy) 
Section: Library Distribution

Revision: 0

Date: September 2005

THIS PAGE INTENTIONALLY LEFT BLANK 